\title{
Diel vertical migration of the krill Meganyctiphanes norvegica in relation to physical environment, food and predators
}

\author{
Maren S. R. Onsrud, Stein Kaartvedt* \\ Department of Biology, University of Oslo, PO Box 1064 Blindern, N-0316 Oslo, Norway
}

\begin{abstract}
A.coustic scattering layers of Meganyctiphanes norvegica in the Oslofjord, Norway, typically stayed below $\sim 70 \mathrm{~m}$ during the day. They remained below prevailing fish schools, though varying numbers of deep-living fish occurred among the krill. The estimated light intensity at the top of the krill layer varied between $4.6 \times 10^{-6}$ and $2.3 \times 10^{-4} \mu \mathrm{mol} \mathrm{m} \mathrm{m}^{-2} \mathrm{~s}^{-1} \mathrm{M}$. norvegica followed isolumes during ascent at dusk, but upward migration was mainly arrested at $\sim 10-30 \mathrm{~m}$ and the krill were scattered throughout the water column at night. The minimum depth was not related to seasonal light levels, chlorophyll concentration or the pycnocline. Fish schools dispersed at sunset, and fish invaded the krill layer at night. Nocturnal avoidance of the surface water may thus have been an antipredator response. Herbivorous feeding was strongly related to abundance of algae (chl a levels). Feeding on phytoplankton increased at night, but daytime stomach pigment content was high during spring, when sedimenting phytoplankton appeared to represent a deep food source. Feeding on copepods was evident both day and night, with no consistent relation between copepod remains in the stomachs and integrated abundance of copepods in the water column. M. norvegica carried out diel vertical migrations irrespective of fluctuations in distribution and abundance of food resources.
\end{abstract}

KEY WORDS: Light - Scattering Jayer - Stomach pigment - Mandibles - Asynchronous migration Planktivorous fish

\section{INTRODUCTION}

The vertical distribution of zooplankton and fish may express a trade-off between food intake and mortality risks (Johnsen \& Jakobsen 1987, Clark \& Levy 1988, Rosland \& Giske 1994), both factors generally increasing towards the surface. Plankton often seem to optimize this trade-off by inhabiting upper, food-rich (and often warm) layers in the shelter of darkness at night, and descending to dim waters during daylight hours to avoid visually searching planktivorous fish. However, presence of pelagic fish in surface waters may induce relatively deep distributions of plankton even at night (Bollens \& Frost 1991, Frost \& Bollens 1992, Loose \& Dawidowicz 1994). Nocturnal upward migrations may likewise be interrupted where suitable feed-

-Addressee for correspondence.

E-mail: stein.kaartvedt@bio.uio.no ing conditions are encountered (Sameoto 1980, Dagg et al. 1997)

Krill are common macroplankters in Norwegian fjords (Hopkins et al. 1978, Falk-Petersen \& Hopkins 1981, Kaartvedt et al. 1988, Kaartvedt \& Svendsen 1990). They are an essential constituent in the diet of fish (e.g. Mauchline 1980, Falk-Petersen \& Hopkins 1981, Dalpadado 1993, Sameoto et al. 1994) and are key organisms in the transfer of energy from lower to higher levels in pelagic food webs. Many of the species are omnivorous and able to utilize a wide variety of food resources.

Krill in Norwegian fjords generally carry out diel vertical migrations (DVM) (Falk-Petersen \& Hopkins 1981, Giske et al. 1990, Kaartvedt \& Svendsen 1990, Baliño \& Aksnes 1993), but the migrational patterns may vary. Baliño \& Aksnes (1993) found that Meganyctiphanes norvegica ascended to the surface at one location but remained below $40 \mathrm{~m}$ at another location 
within the same fjord. Little is known about factors underlying the flexibility of their behavior. In the present study, DVM and in situ feeding behavior of $M$. norvegica were examined under contrasting physical conditions and abundances and distributions of food and predators in an attempt to unveil driving forces shaping vertical migration patterns.

\section{MATERIALS AND METHODS}

Study area and periods. The study was carried out at a $\sim 120 \mathrm{~m}$ deep station in the inner Oslofjord, Norway, during the periods 30 November-1 December 1994 and 30-31 March, 26-27 June and 28-30 November 1995. The RV 'Trygve Braarud' was anchored at a fixed position during the studies. The water column of the inner Oslofjord can roughly be divided into the basin water below sill depth $(19 \mathrm{~m})$ and the surface waters above sill depth. The basin water exhibits only minor vertical and seasonal variations in salinity and temperature, while the oxygen content fluctuates and may reach critical levels locally. Renewal of the basin water normally occurs each year during late autumn or winter by influx of water from outside the sill. Above sill depth, salinities and temperatures vary considerably. Tidal exchange is limited, with amplitudes of about 20 to $30 \mathrm{~cm}$ (Beyer 1992).

Hydrography, oxygen and light measurements. Temperature and salinity profiles were obtained twice daily with a Neil Brown Mark III CTD. Water samples for measurement of dissolved oxygen were collected with Niskin water bottles (not sampled in June). Preservation of the water samples and subsequent analysis in the laboratory was performed according to the modified Winkler procedure outlined by Strickland \& Parsons (1972).

Surface light $(400-700 \mathrm{~nm})$ was recorded continuously by a $2 \pi$ LiCor 190 SA quantum sensor coupled to a LiCor-1000 data logger. Logging failed in June and during most of the study in November 1995. Surface light data for June (global flux; $\mathrm{J} \mathrm{m}^{-2}$ ) were obtained from the Agricultural University of Norway, located about $10 \mathrm{~km}$ from the sampling station. These data were transformed using the relationship $1 \mathrm{~J} \mathrm{~m}^{-2}=$ $2 \mu \mathrm{mol} \mathrm{m}{ }^{-2} \mathrm{~s}^{-1}$ (Eyvind Aas, Geophysical Institute, University of Oslo, pers. comm.). Light extinction coefficients were estimated at noon from subsurface light intensity measurements in the upper $30 \mathrm{~m}$ with a spherical LiCor 193SA quantum sensor. Light intensity at the upper boundary of the acoustic scattering layer of krill (see below) was estimated by extrapolation, using Beer's law. During upward migration, light levels at the upper boundary of the migrating layer were calculated for approximately every 5 to 10 min using sur- face light from the same minute and light extinction coefficients determined from the subsurface light measurements at noon.

Biological sampling and analysis. During the first 3 surveys, samples for pigment analyses were taken using Niskin bottles every $1 \mathrm{~m}$ in the upper $10 \mathrm{~m}$, every $2 \mathrm{~m}$ down to $30 \mathrm{~m}$, and every $7 \mathrm{~m}$ down to $114 \mathrm{~m}$. Samples from each of the 1-10, 10-30 and 30-114 $\mathrm{m}$ intervals were mixed, and subsamples of 50 to $200 \mathrm{ml}$ of water (volume depending on phytoplankton concentration) taken from the integrated samples were filtered onto Whatman glass microfibre filters (GF/F) for measurements of particulate pigments. The filters were immediately frozen and later analyzed for extracted chlorophyll a (chl a) according to procedures outlined in Strickland \& Parsons (1972). Three replicate series were taken in November 1994 and in June 1995, while sampling was unreplicated in March and November 1995. The protocol was changed in November 1995, when water samples for pigments were analyzed for discrete depths $(0,5,12$, $20,30,37,62,87$ and $105 \mathrm{~m}$ ).

Mesozooplankton was collected in 3 to 5 depth intervals both day and night, using a WP2 net with $200 \mu \mathrm{m}$ mesh size. The net was hauled vertically at $50 \mathrm{~cm} \mathrm{~s}^{-1}$, and filtered volumes were estimated by multiplying towing distance with net aperture. During the first 3 surveys, 3 to 4 replicate series were taken day and night in the 115-30, 30-10 and 10-0 m depth intervals and the content split in two by a modified Folsom splitter. One half was sieved through a $2 \mathrm{~mm}$ mesh, and biomass (dry weight) measured for the passing plankton retained on a $200 \mu \mathrm{m}$ sieve. The other half was preserved in $4 \%$ buffered formaldehyde in seawater for enumeration. This fraction was further subsampled by a modified Lea-Wiborg divider, and subsamples of at least 500 individuals were counted. The biomass measurements showed little variation between replicated net tows (Vedal 1997), and enumeration was therefore only made from 1 day and 1 night series. In November 1995, only 1 day and 1 night series were taken and the whole samples were fixed for enumeration. Sampling depths were then 115-100 $\mathrm{m}$ and thereafter $25 \mathrm{~m}$ intervals to the surface.

Krill were collected in 4 to 5 depth intervals, using a modified Nansen net (Kirkerud 1974). The meshsize was $500 \mu \mathrm{m}$ and the opening diameter $103 \mathrm{~cm}$. The net was hauled vertically at $0.75 \mathrm{~m} \mathrm{~s}^{-1}$. Sampling depths were $115-60,60-30,30-10$ and $10-0 \mathrm{~m}$ in November 1994, while the deepest interval was further subdivided in two (115-100 and 100-60 m) in March 1995. There was no sampling of krill in June. As for mesozooplankton, sampling depths in November 1995 were $115-100 \mathrm{~m}$ and thereafter $25 \mathrm{~m}$ intervals to the surface. Three to four replicate full series were taken 
both day and night, with additional sampling in depths with peak krill abundance to obtain sufficiently high numbers of individuals for stomach analyses. Krill analyzed for gut pigment were rinsed in distilled water, quickly dried on absorbent tissue and frozen $\left(-18^{\circ} \mathrm{C}\right)$ in aluminium envelopes within 5 min after the net was on deck. The rest of the catches was preserved in a $4 \%$ buffered solution of formaldehyde in seawater.

Ship's lights may cause avoidance by krill during the night (Sameoto et al. 1985). The floodlights on deck were therefore turned off during night operations, but some light was necessary to allow the work. Catches of krill were relatively low during the day. To reduce avoidance, the net was equipped with a light source during the November 1995 sampling (cf. Sameoto et al. 1993). A strobe light, emitting 100 flashes of $45 \mathrm{~W}$ per minute, mounted in a waterproof housing was fastened to the net frame, the light flashing upwards. A preliminary test during daytime prior to the November 1995 sampling indicated an on average 2 to 3 times increase in net catches with the use of light. Sampling may still not have been quantitative, but served its purpose of revealing the main patterns of the vertical distributions, allowing species identification in the acoustic scattering layer, and providing individuals for stomach analysis.

All krill were identified to species, and total length (tip of rostrum to tip of telson) was measured to the nearest $\mathrm{mm}$. Stomach and hindgut were dissected from individuals larger than $18 \mathrm{~mm}$, although most individuals were larger than $30 \mathrm{~mm}$ except in March. Stomach fullness was subjectively estimated using an index from 0 (completely empty) to 4 (completely full). Stomachs and hindguts from frozen euphausiids were put into a test tube with $10 \mathrm{ml} 90 \% \mathrm{MgCO}_{3}$ buffered acetone, and extracted for $24 \mathrm{~h}$ in the dark at $4^{\circ} \mathrm{C}$ (Simard et al. 1986). Fluorescence was measured with a Turner Design fluorometer. Fluorescence background levels due to stomach tissues were considered to be negligible (Simard et al. 1986). Krill content of chl a and the chlorophyll equivalent of pheopigments were calculated according to equations in Dagg \& Walser (1987). These values were summed to give total pigments. Stomachs from formalin preserved euphausiids were removed and the contents examined at $125 \times$ magnification for presence of copepod mandibles.

Individuals $>30 \mathrm{~mm}$ were tested for differences in gut pigment content between depths and day and night by the non-parametric single-factor KruskalWallis test and the non-parametric Dunn's multiple comparison test (Zar 1996). Relations between stomach pigment content and integrated water column chl a during the different cruises were tested by simple linear regression $\left(\log _{10}\right.$ transformed data). Potential differences in stomach content of copepod mandibles between day and night and between cruises were tested by ANOVA (square-root transformed data).

Acoustic studies. Krill are often concentrated in acoustic scattering layers (e.g. Greenlaw 1979, Pieper 1979, Falk-Petersen \& Hopkins 1981, Simard \& Mackas 1989, Beyer 1992, Greene et al. 1992). We used Simrad EK $500120 \mathrm{kHz}$ split-beam and $38 \mathrm{kHz}$ split-beam hull-mounted echo-sounders for studies of krill and fish. The transducer depth was $1.8 \mathrm{~m}$, which is accounted for in the software. The echo-sounders were in continuous operation. Data acquisition and post-processing was achieved using the computer-based EP500 software (Lindem \& Al Houari 1993). The $120 \mathrm{kHz}$ echograms were also continuously printed on paper.

The size of the acoustic targets is critical for their detection at different frequencies. Meganyctiphanes norvegica grow to a maximum length of about $4.4 \mathrm{~cm}$ in the study area, and most individuals from the net catches were $>30 \mathrm{~mm}$ (Onsrud 1997). In November 1994, the length distribution of $M$. norvegica peaked at $32 \mathrm{~mm}$, though with a few smaller individuals (peak at $15 \mathrm{~mm}$ ). In March, the length distribution was bimodal, with peaks at 24 and $35 \mathrm{~mm}$. The population in November 1995 consisted almost exclusively of large individuals, with a peak at $35 \mathrm{~mm}$. Their size was thereby well above the wavelength at $120 \mathrm{kHz}$ (13 $\mathrm{mm})$ and therefore within the geometric scattering zone at $120 \mathrm{kHz}$. In other words, backscattering represents a quantitative abundance estimate. Most individuals were, on the other hand, smaller than the wavelength at $38 \mathrm{kHz}(39 \mathrm{~mm})$. They were therefore within the Rayleigh scattering zone (i.e. backscattering decreases exponentially with decreasing size) and accordingly weak targets at this frequency (Greene et al. 1991).

Meganyctiphanes norvegica appeared to be the major acoustic target in a diffuse scattering layer (SL) which appeared clearly at $120 \mathrm{kHz}$, but was hardly detectable at $38 \mathrm{kHz}$ (see Fig. 3). During the entire study period, a total of 116 vertical net hauls were taken in this SL, yielding $1292 \mathrm{M}$. norvegica. Fiftyfive casts were directed outside the layers, yielding only $6 \mathrm{M}$. norvegica in total. Thysanoessa raschi probably contributed significantly to the backscattering in November 1994, when this was the most common krill species. However, most $T$. raschi were smaller than $17 \mathrm{~mm}$ and thus weaker targets. $T$. raschi were almost absent during the other surveys. Copepods and chaetognaths were the only other prevailing taxa in the catches. Their distributions were not specifically associated with the $120 \mathrm{kHz}$ SLs, and they were not present in sufficient numbers to contribute significantly to the recorded volume backscattering. 


\section{RESULTS}

\section{Physical environment and potential food}

Temperatures of the basin water were 6 to $8^{\circ} \mathrm{C}$ year round (Fig. 1). The lower boundary of the pycnocline was generally located between 15 and $20 \mathrm{~m}$. Above, the temperature decreased to a surface minimum of 4 to $5^{\circ} \mathrm{C}$ in November (both years) and March, and increased to a maximum of $19^{\circ} \mathrm{C}$ in June. The salinity

November 1994

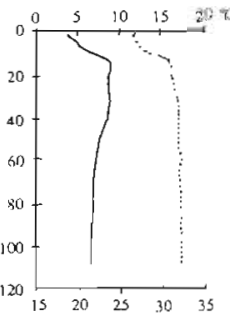

March 1995

June 1995

Temperature $\left({ }^{\circ} \mathrm{C}\right.$ ) and salinity (ppt)
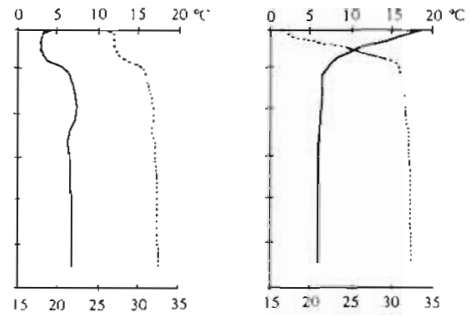

Oxygen $\left(\mathrm{ml} \mathrm{l}^{-1}\right)$
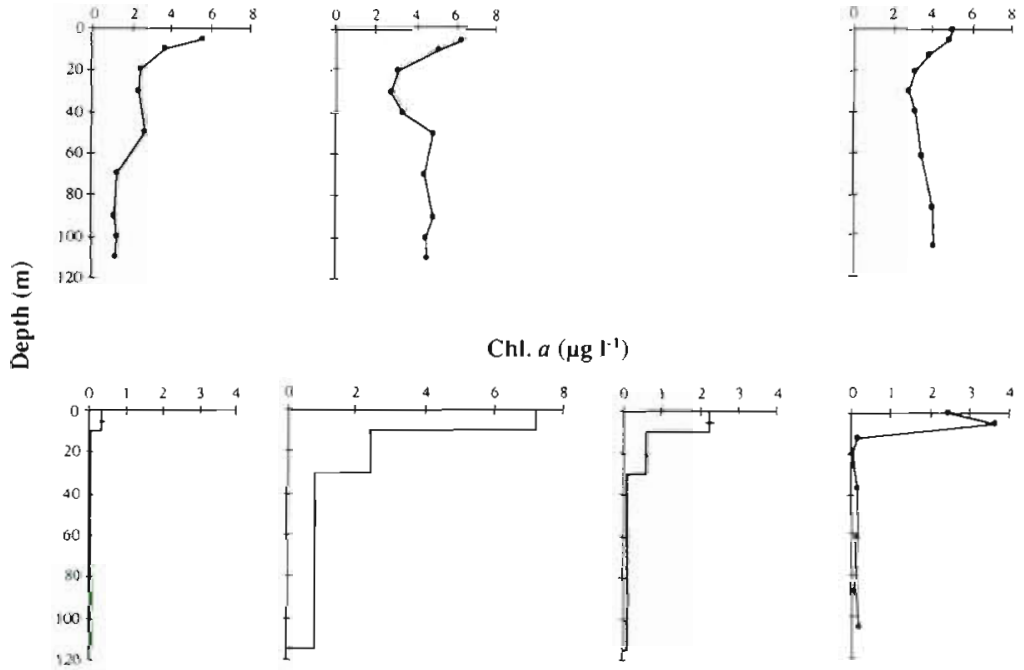

1201

Copepods $\mathrm{m}^{-3}$
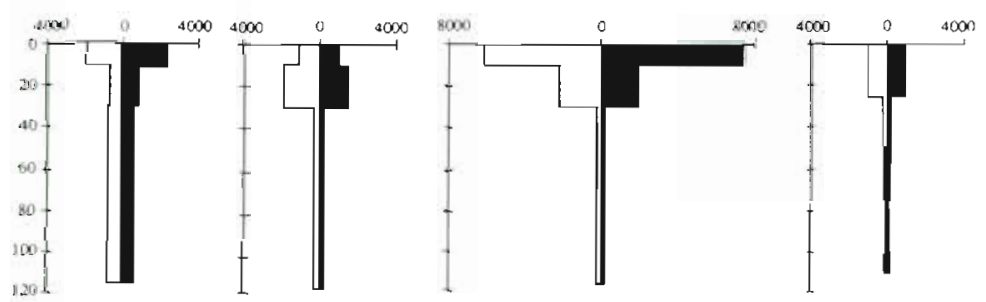

Fig. 1. Vertical distributions of temperature (solid line, upper $x$-axis) and salinity (dotted line, lower $x$-axis); oxygen, chl a and copepods during the day (open) and at night (black). Profiles for chl a in November 1994 and June 1995 represent means from 3 replicates, with standard errors given. Other profiles are from unreplicated samples of the basin water changed little between study periods, varying between 32 and 33 ppt. The salinity decreased toward the surface, with a minimum of $16 \mathrm{ppt}$ in June. The surface values varied between 26 and $29 \mathrm{ppt}$ for the 3 other surveys. The oxygen content below $70 \mathrm{~m}$ was low in November 1994 (about $1.3 \mathrm{ml}$ $\mathrm{I}^{-1} \mathrm{j}$, while the deep water during other sampling periods was well oxygenated (Fig. 1). The 1\% light depth was located at about $8 \mathrm{~m}$ in March, 13 to $14 \mathrm{~m}$ in November 1994 and June 1995, and $20 \mathrm{~m}$ in November 1995.

Concentrations of chl a were at a minimum in November 1994 (Fig. 1) and at a maximum in March, with values of $\sim 7 \mu \mathrm{g} \mathrm{l}^{-1}$ in the upper $10 \mathrm{~m}$, and $0.8 \mu \mathrm{g}$ $\mathrm{l}^{-1}$ in the $30-114 \mathrm{~m}$ layer. In November 1995 , the chl a values were considerably higher than in the previous year.

The highest concentrations of copepods were generally found in upper layers, but relatively high numbers occurred below $30 \mathrm{~m}$ in November 1994 (Fig. 1). The copepods in the deepest interval were then mainly overwintering Calanus spp., and their actual concentrations in the lower part of the water column were probably underestimated due to the large sampling range. The copepods in the upper layers (Fig. 1) were mainly small genera like Oithona, Acartia, Temora and Pseudocalanus, but with some Calanus spp. in March and high numbers of Centropages spp. in June.

\section{Distribution of krill}

The net tows (Fig. 2) and acoustic data (Fig. 3) suggested that Meganyctiphanes norvegica were restricted to waters deeper than $70 \mathrm{~m}$ during the day. The day depth of the krill scattering layer (SL) at $120 \mathrm{kHz}$ was fairly constant between surveys, although the estimated light intensity at the top of the layer was 2 orders of magnitude less in March than during the other surveys (Table 1 ).

Krill ascended at night (Figs. 2 \& 3), but were still captured in the deepest net tows. Ascent and descent (the latter only studied in November 1995) of the SL followed sigmoidal curves, indicating varying migration velocities from the start to the end of migration. The maximum migration velocity was least in June $\left(15 \mathrm{~m} \mathrm{~h}^{-1}\right)$, and approximately 


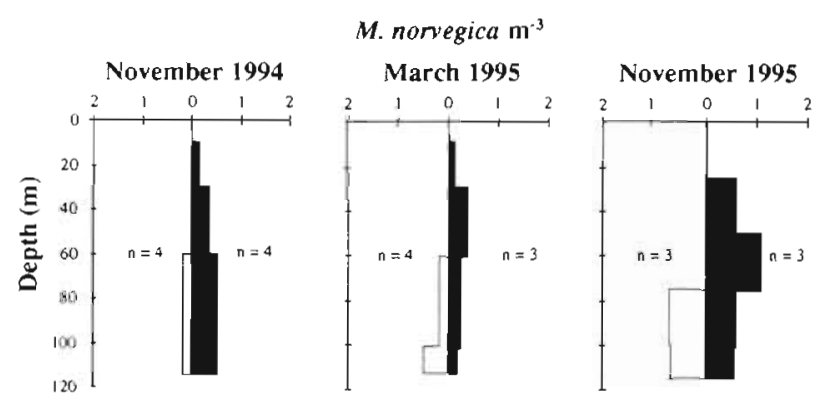

Fig. 2. Meganyctiphanes norvegica. Day (open) and night (black) vertical distribution as determined by vertical net tows. $\mathrm{n}=$ number of replicate profiles

equal for the other study periods $\left(-40 \mathrm{~m} \mathrm{~h}^{-1}\right.$; Table 1$)$. The ascent appeared to be closely linked to light levels, and the upper boundary of the SL followed the daytime isolume (Fig. 4). When approaching upper waters, the SL remained deeper than the isolume. The minimum depth of the SL varied between periods, and was shallowest $(10 \mathrm{~m}$ ) in June 1995 and deepest (30 m) in November 1995. Very few krill were caught in the upper 30 (25) $\mathrm{m}$. However, by employing split-beam analysis to estimate the target strength (TS) distribution, some -80 to $-68 \mathrm{~dB}$ targets were detected above the SL. These TS values correspond to krill-sized targets. Such targets were not detected by day.

\section{Distribution of fish}

Fish targets are clearly visible also at $38 \mathrm{kHz}$. Fish were most abundant in November 1995, and least abundant in June (Fig. 3). Schools were located at about $50 \mathrm{~m}$ during the day, i.e. above the krill layer. In November 1995, additional conspicuous non-schooling fish echoes occurred together with the krill.

The fish distributions changed markedly throughout the diel cycle. Schools dispersed at sunset, when the fish invaded the ascending krill layer, and the fish reassembled into schools before sunrise (Fig. 3). Watercolumn echoes at $38 \mathrm{kHz}$ in June were mainly from fish leaving the benthic boundary zone at dusk and ascending into the water column in concert with the krill.

\section{Krill feeding}

No individual with a completely empty stomach was found among the 834 specimens analyzed. The mean stomach fullness of Meganyctiphanes norvegica was always between $1 / 2$ and $3 / 4$ full. Gut pigment contents were strongly related to in situ pigment levels (Fig. 5; linear regression, $p<0.0001$ ). Grazing increased by night (Fig. 5; Kruskal-Wallis test, Dunn's test, $\mathrm{p}<0.0001$ ). No consistent differences in nocturnal gut pigment content were found between depth layers. The $24 \mathrm{~h}$ study in November 1995 revealed enhanced feeding at the end of the night (Fig. 6). The subsequent in situ gut evacuation rate $(k)$ during krill descent was estimated at $0.56 h^{-1}$ $\left(\mathrm{R}^{2}=0.91\right)$ by applying the relationship $G_{t}=G_{0} \mathrm{e}^{(-k t)}$. $\left(G_{0}\right.$ and $G_{t}$ are the initial and final average gut pigment levels, respectively; Perissinotto \& Pakhomov 1996). A positive relationship between the total gut pigment content and krill wet weight (ww) was found by night in March 1995 [p $<0.01, \log _{10}$ (total pigment) (ng) $=0.0059 \mathrm{ww}(\mathrm{mg})+1.27, \mathrm{R}^{2}=0.53 \mathrm{j}$. No clear relations between gut pigment content and krill weight were revealed for the November cruises, but the size range of the krill analyzed was then much smaller.

Of the stomachs analyzed microscopically $(n=328)$, $93 \%$ contained recognizable copepod remains, with $84 \%$ containing mandibles. The highest stomach contents of mandibles were found at the highest ambient copepod abundance (Fig. 7), with a significantly higher degree of daytime carnivory on copepods in November 1994 than in March and November 1995 (ANOVA, p < 0.01). However, there was no consistent relationship between the numbers of mandibles in the stomachs and the integrated abundance of copepods in the water column. Night-time carnivory on copepods was higher during the 2 November periods, one with high and one with low ambient copepod numbers, than in March, with intermediate copepod numbers (ANOVA, $\mathrm{p}<0.05$ ). No significant differences between day and night ingestion of copepods, nor any relations between Meganyctiphanes norvegica wet weight and the number of copepod mandibles in the stomachs, were found.

Table 1 Summary information on the $120 \mathrm{kHz}$ scattering layer (SL). The depth of the upper boundary of the SL was assessed from the original paper prints, using a Sv (volume backscattering) threshold of $-75 \mathrm{~dB}$

\begin{tabular}{|lccccc|}
\hline & Nov 1994 & Mar 1995 & Jun 1995 & Nov 1995 & Units \\
\hline Light level, upper boundary (noon) & $2.3 \times 10^{-4}$ & $4.6 \times 10^{-6}$ & $1.2 \times 10^{-4}$ & $1.3 \times 10^{-4}$ & $\mu \mathrm{mol} \mathrm{m}^{-2} \mathrm{~s}^{-1}$ \\
Depth, upper boundary (noon) & 72 & 73 & 70 & 73 & $\mathrm{~m}$ \\
Depth, upper boundary (night) & 20 & 25 & 10 & 30 & $\mathrm{~m}$ \\
Maximum migration velocity & 40 & 38 & 15 & 40 & $\mathrm{~m} \mathrm{~h}^{-1}$ \\
\hline
\end{tabular}



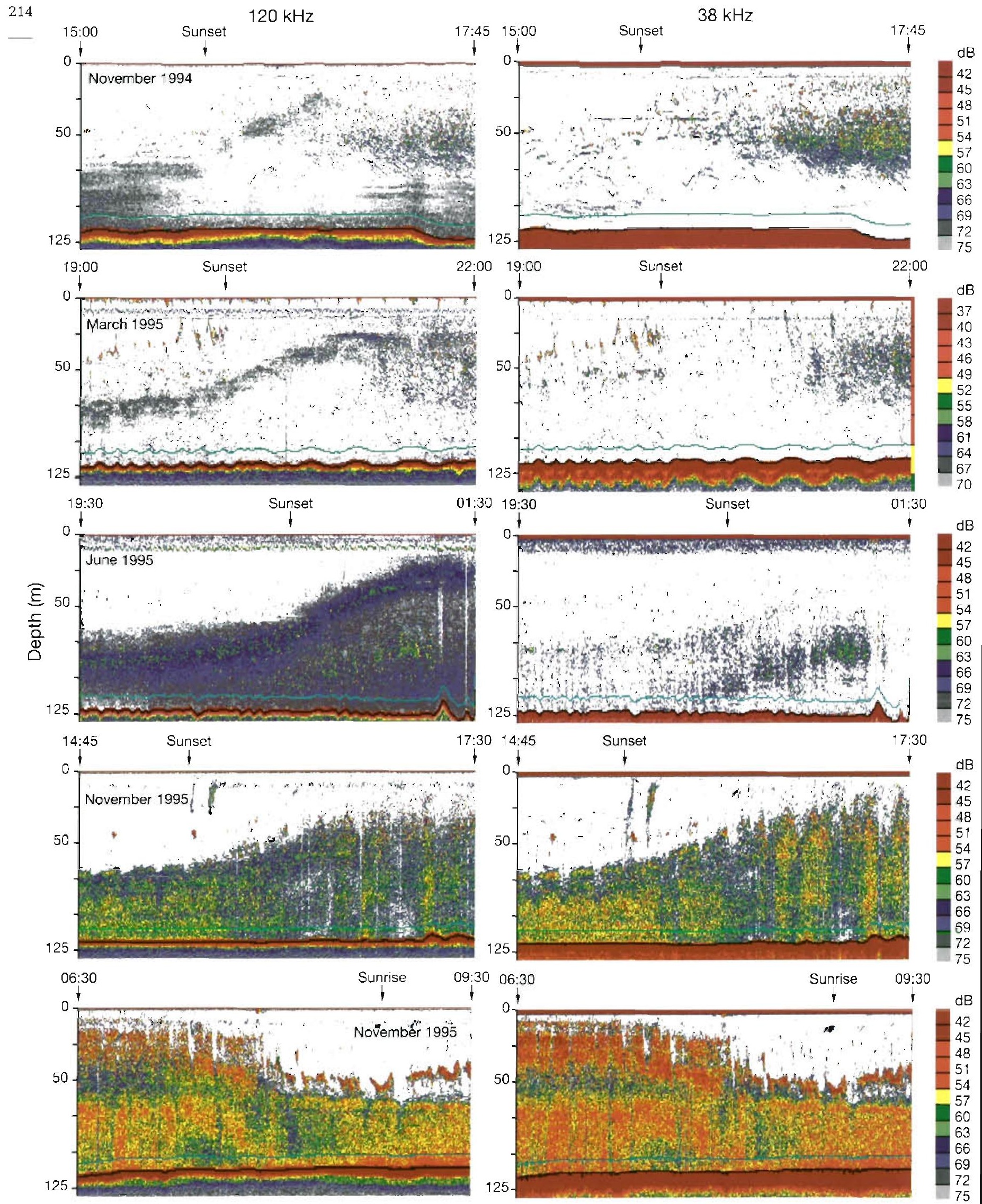

Time

Fig. 3. Acoustic records at 120 and $38 \mathrm{kHz}$. Color bars denote volume backscattering (Sv). Note that the threshold (color code) used in March differs from the other surveys 
Time before and after sunset (min.)
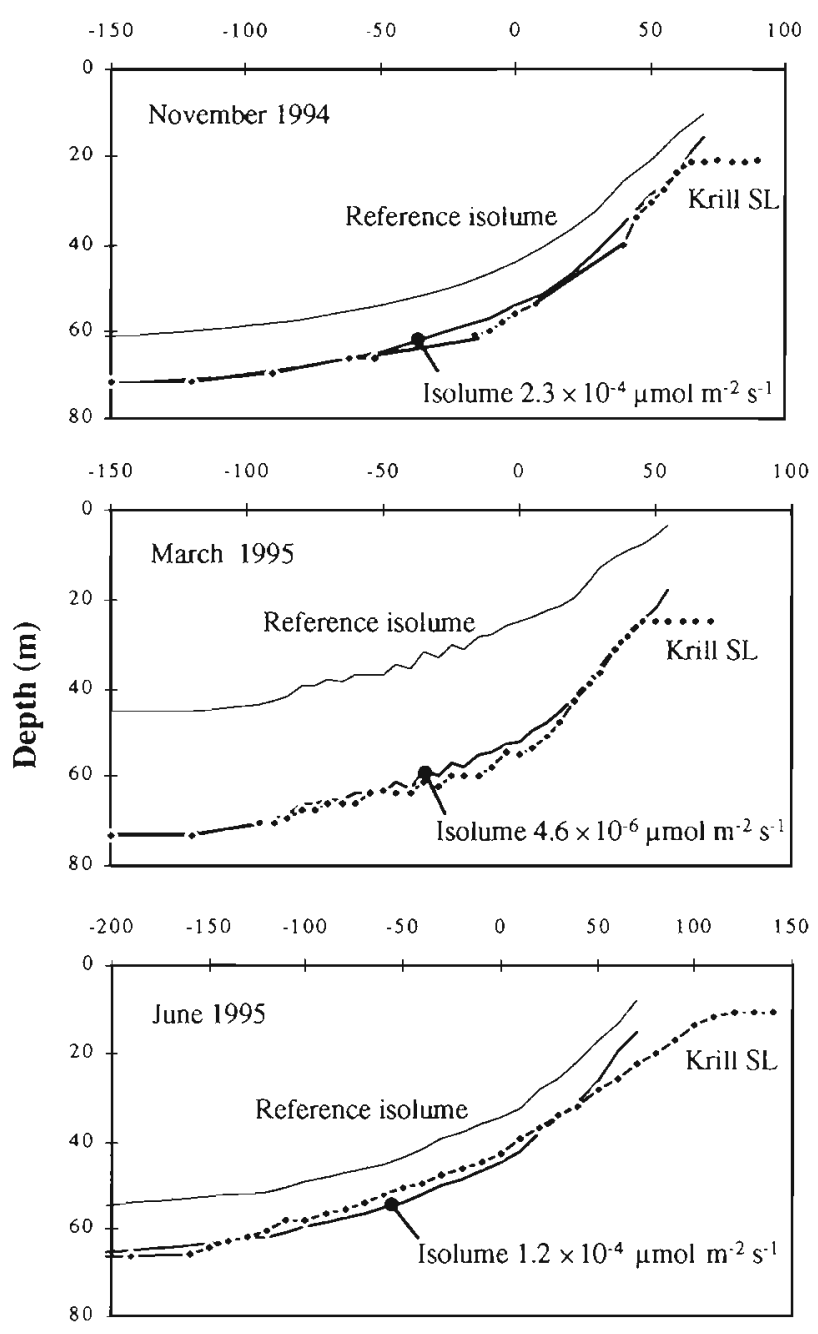

Fig. 4. Positions of isolumes $(\bullet)$ and upper boundary of the krill scattering layers ( $\bullet$ ) during the transition zone from day to night. Positions of the $10^{-3} \mu \mathrm{mol} \mathrm{m} \mathrm{m}^{-2} \mathrm{~s}^{-1}$ isolume at the different cruises are given as references

\section{DISCUSSION}

\section{DVM and feeding cycles}

Herbivorous feeding in Meganyctiphanes norvegica reflected the availability of food. This comprised high gut pigment levels by day in March, when sinking phytoplankton appeared to supply algae to the daytime habitat. Sedimentation of algae is a normal phenomenon during late bloom stages (Wassmann 1991, Tiselius \& Kuylenstierna 1996). M. norvegica still displayed marked nocturnal increases in gut pigment levels on all occasions, as also found in previous reports on this and other species (Mauchline \& Fisher 1969, Sameoto 1980, Simard et al. 1986, Stuart \& Pillar

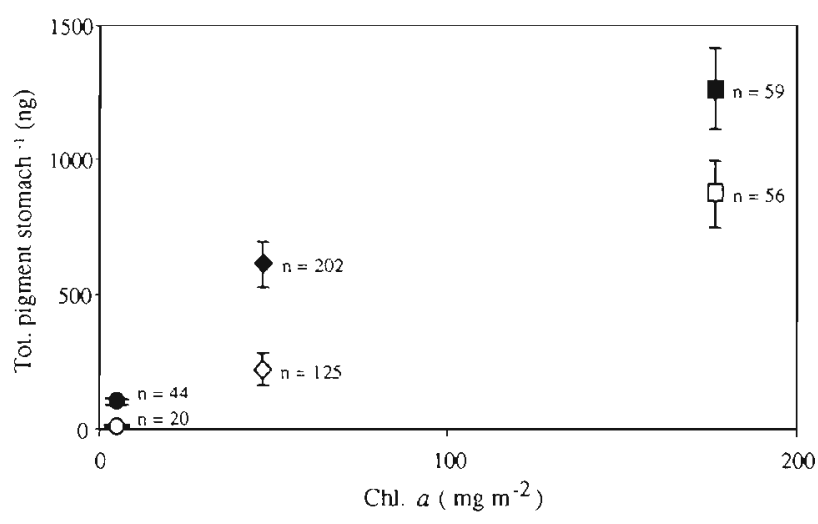

Fig. 5. Meganyctiphanes norvegica. Average stomach pigment contents of krill $>30 \mathrm{~mm}$ by day (open) and night (black) related to surface integrated chl a values in November 1994

$(\bullet, \circ)$ and March $(\bullet$, 口) and November $1995(\bullet, \diamond)$. Standard errors are shown. $\mathrm{n}=$ number of individuals examined

1990, Gibbons 1993). The diel feeding rhythm was associated with vertical migrations towards food-rich, upper layers. To access the enhanced food sources near the surface, individuals would, however, need to make feeding excursions above the upper limits of the recorded SLs by night. Estimates based on krill filtration and egestion rates (McClatchie 1985), combined with the water column chl a concentrations, suggest that this indeed would be necessary to obtain the measured gut content of the krill in November of both years (Onsrud 1997).

Asynchronous feeding migrations were suggested by large individual differences in gut pigment levels. Individuals with empty guts apparently arrived in shallow water throughout the night (cf. Williams \& Fragopoulu 1985, Simard et al. 1986), as gut content varied by more than an order of magnitude (e.g. ranging from 80 to $3880 \mathrm{ng}$ ind.$^{-1}$ in the $50-25 \mathrm{~m}$ stratum at 07:35 h in November 1995). The very high gut content at the end of the night in November 1995 remains to be explained. The estimated in situ average gut evacuation rate $\left(0.56 \mathrm{~h}^{-1}\right)$ suggests that the hypothetical recurrent feeding migrations are warranted. This rate agrees with estimates from incubation experiments, where averages ranged from 0.41 to $0.63 \mathrm{~h}^{-1}$ (Drits \& Semenova 1989, Daly 1990, Drits \& Pasternak 1993).

Correspondingly, individuals with an order of magnitude higher gut pigment content than day samples were caught below $100 \mathrm{~m}$ early in the evening. Enhanced nocturnal gut concentrations at depth could then arise from feeding in shallower water followed by 'midnight sinking' (cf. Gibbons 1993). Diel cycles in stomach pigment content may, however, also have a behavioral basis, occurring irrespective of changes in ambient food concentrations. Feeding affects gut con- 


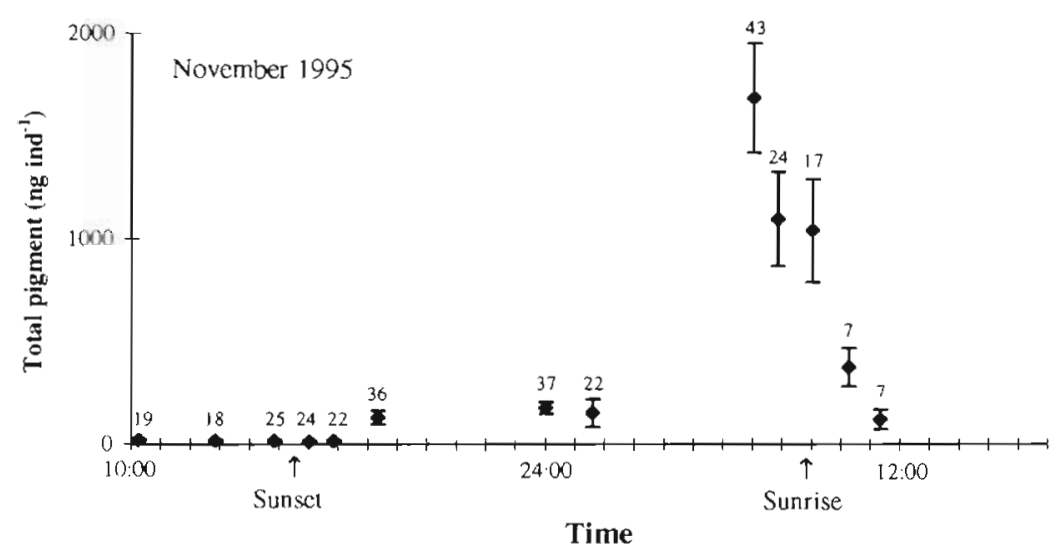

Fig. 6. Meganyctiphanes norvegica. Diel variation in average stomach pigment content of krill $>30 \mathrm{~mm}$ on 29-30 November 1995. Standard errors are shown, and numbers above data points denote numbers of individuals examined

(November 1994 and March 1995, respectively), and individuals left the basin water when deep copepod concentrations were both low and high.

\section{DVM and hydrography}

The apparent avoidance of the upper layer at night is probably not related to hydrography. Krill were not caught above $25 \mathrm{~m}$ in November 1995, in spite of weak vertical temperature and salinity gradients at this time. Furthermore, by analysing in situ target strength (TS) with the split-beam data, it appeared that some individuals migrated through the pycnocline during all study periods,

trast and motion and makes plankton more susceptible to visual predators (cf. Bollens \& Stearns 1992).

Almost all Meganyctiphanes norvegica stomachs contained copepods. The krill evidently obtained a lot of food by carnivorous feeding in their daytime habitat in November 1994, when relatively high concentrations of overwintering Calanus spp. inhabited the deep waters. Accumulation of overwintering copepods in the basin water may contrast with the usual pattern of increased food concentration towards the surface. Nevertheless, $M$. norvegica ascended at night. Also, Sameoto (1980) noted that $M$. norvegica left abundant copepod prey during nocturnal ascent, and suggested that a varied diet was necessary to satisfy nutritional needs.

In conclusion, Meganyctiphanes norvegica carried out DVM irrespective of fluctuations in food abundance and distribution. $M$. norvegica migrated when chlorophyll values were at both the lowest and highest

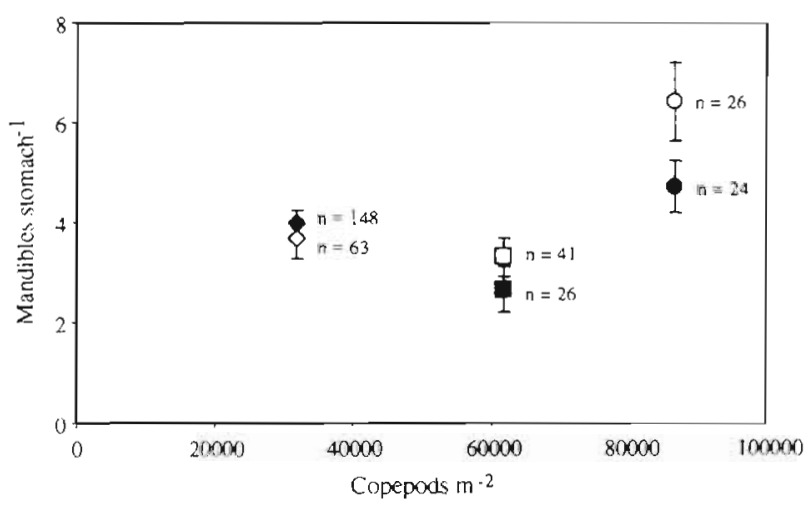

Fig. 7. Meganyctiphanes norvegica. Average stomach content of copepod mandibles for krill $>30 \mathrm{~mm}$ by day (open) and night (black) related to surface-integrated numbers of copepods (averages for day and night tows) in November $1.994(\bullet, \circ)$ and March $(\bullet$, a) and November $1995(\bullet, \bullet)$. Standard errors are shown. $n=$ number of individuals examined suggesting that the pycnocline did not represent an impenetrable barrier. Physical gradients were strongest during the one occasion when the upper fraction of the SL appeared to migrate into the near-surface water (June). Migration into the warmer upper waters could then actually have represented a benefit through increased growth rate (cf. Kerfoot 1985, Wurtsbaugh \& Neverman 1988, Williamson et al. 1996).

Some previous studies have shown that Meganyctiphanes norvegica migrates through pycnoclines (Mauchline \& Fisher 1969, Simard et al. 1986), while others have suggested that pycnoclines may hinder upward migrations at night (Kaartvedt \& Svendsen 1990, Buchholz et al. 1995, Bergström \& Strömberg 1997). These differences in behavior may be related to the actual physical gradients involved, but pertinent alternative explanations have generally not been evaluated when arrest of upward migration has been ascribed to the hydrography.

\section{DVM, light levels and predators}

Meganyctiphanes norvegica lived below $\sim 70 \mathrm{~m}$ during the day. This is shallower than in fjords along the western Norwegian coast, where they mainly stay below $100 \mathrm{~m}$ (e.g. Evans \& Hopkins 1981, Giske et al. 1990, Baliño \& Aksnes 1993). This may be explained by light conditions. The $1 \%$ light depths were shallower than for the other reports on krill distribution (Hopkins et al. 1978, Evans \& Hopkins 1981, Balin̄o \& Aksnes 1993), and high amounts of light-absorbing matter is present below the euphotic zone in Oslofjorden (up to about $100-120 \mu \mathrm{mol}$ dissolved organic carbon; $\mathrm{M}$. Abdullah, Department of Biology, University of Oslo, pers. comm.). The light levels calculated at the upper 
boundary of the SL (ranging from $4.6 \times 10^{-6}$ to $2.3 \times$ $10^{-4} \mu \mathrm{mol} \mathrm{m} \mathrm{m}^{-2} \mathrm{~s}^{-1}$ ) corresponded fairly well with previous reports on M. norvegica (Sameoto 1980, Andersen \& Nival 1991)

The lower threshold for visual predation of herring can be estimated to be about $10^{-5} \mu \mathrm{mol} \mathrm{m}{ }^{-2} \mathrm{~s}^{-1}$ [based on data of Blaxter (1970) and conversions from lux; McCree (1981)]. The krill and the schooling fish (acoustic signatures suggest clupeids) were consistently vertically segregated during the day in Oslofjorden, and the krill migration pattern thus appeared to prevent diurnal predation from these planktivores. However, the light levels suggest that visual predation is possible during the day, at least at the top of the krill layer by some fish species. Other fish were indeed present among the krill, especially in November 1995. Norway pout Trisopterus esmarki, whiting Merlangius merlangus and cod Gadus morhua are among the potential diurnal predators in this location (Tom Larson \& Anders Røstad, Department of Biology, University of Oslo, unpubl. trawl surveys). Possibly, the low oxygen value below $70 \mathrm{~m}$ in November $1994\left(-1.3 \mathrm{ml} \mathrm{l}^{-1}\right)$ created a refuge for the krill by constraining the distribution of fish. Deep-living fish were almost absent at this time.

During nocturnal ascent, the upper boundary of the migrating SL appeared to follow the ascending daytime isolume. This contrasts with most previous studies on krill and other zooplankton. None of the 5 euphausiid species studied by Roe (1983) followed an isolume during migration. Andersen \& Nival's (1991) model for DVM of Meganyctiphanes norvegica is based on the assumption that migration is initiated by the rate of intensity change. Ringelberg (1995) stated that relative changes in light intensity at dawn and dusk were the primary stimuli evoking migrations among plankton, and that plankton generally did not follow isolumes.

Meganyctiphanes norvegica ascended to the shallowest depth in June, even though twilight prevailed throughout the short summer night. The abundance of pelagic fish was, however, at a minimum at that time, with fish ascending from the benthic boundary zone being the major potential nocturnal predators. Conversely, the upward migration was most clearly arrested at subsurface depth in November 1995, when pelagic fish abundance was maximal. Herring, Norway pout and cod also feed on krill at night (Pearcy et al. 1979, Asttorsson \& Pálsson 1987, Dalpadado 1993. Albert 1994, Torgersen 1995). A strategy that would limit predation by nocturnally active planktivores would therefore be an adaptive one (cf. Bollens \& Frost 1991, Dawidowicz \& Loose 1992, Frost \& Bollens 1992, Loose \& Dawidowicz 1994j. A dynamic feedingmigratory behavior whereby individuals move between the food-rich surface layer and deeper water throughout the night (cf. the hunger-satiation hypothesis; Conover 1968, Rudjakov 1970) would minimize the amount of time spent in surface waters and may thereby reduce predation risk.

Acknowledgements. We thank Jens Vedal for access to data on chl a and copepods, and the captain and crew of 'Trygue Braarud' for skillful assistance during the sampling. Comments from Espen Bagøien improved the manuscript.

\section{LITERATURE CITED}

Albert OT (1994) Biology and ecology of Norway pout (Trisopterus esmarki Nilsson, 1855) in the Norwegian deep. ICES J Mar Sci 51:45-61

Andersen V, Nival P (1991) A model of the diel vertical migration of zooplankton based on euphausiids. J Mar Res 49: $153-175$

Astthorsson OS, Pálsson OK (1987) Predation on euphausiids by cod, Gadus morhua, in winter in Icelandic subarctic waters. Mar Biol 96:327-334

Balino BM, Aksnes DL (1993) Winter distribution and migration of the sound scattering layers, zooplankton and micronekton in Masfjorden, western Norway. Mar Ecol Prog Ser 102:35-50

Bergström B, Strömberg JO (1997) Behavioural differences in relation to pycnoclines during vertical migration of the euphausiids Meganyctiphanes norvegica (M. Sars) and Thysanoessa raschii (M. Sars). J Plankton Res 19:255-261

Beyer F (1992) Meganyctiphanes norvegica (M. Sars) (Euphausiacea), a voracious predator on Calanus, other copepods, and ctenophores, in Oslofjorden, Southern Norway. Sarsia 77:189-206

Blaxter JHS (1970) Light, animals, fishes. In: Kinne O (ed) Marine Ecology, Vol 1, Part 1. Wiley-Interscience, London, p $213-320$

Bollens SM, Frost BW (1991) Ovigerity, selective predation, and variable diel vertical migration in Euchaeta elongata (Copepoda: Calanoida). Oecologia 87:155-161

Bollens SM, Stearns DE (1992) Predator-induced changes in the diel feeding cycle of a planktonic copepod. J Exp Mar Biol Ecol 156: 179-186

Buchholz F, Buchholz C, Reppin J, Fischer J (1995) Diel vertical migrations of Meganyctiphanes norvegica in the Kattegat: comparison of net catches and measurements with Acoustic Doppler Current Profilers. Helgol Meeresunters 49:849-866

Clark CW, Levy DA (1988) Diel vertical migration by juvenile sockeye salmon and the antipredation window. Am Nat $131: 271-290$

Conover RJ (1968) Zooplankton-life in a nutritionally dilute environment. Am Zool 8:107-118

Dagg MJ, Frost BW, Newton JA (1997) Vertical migration and feeding behavior of Calanus pacificus females during a phytoplankton bloom in Dabob Bay, U.S. Limnol Oceanogr 42:974-980

Dagg MJ, Walser WE Jr (1987) Ingestion, gut passage, and egestion by the copepod Neocalanus plumchrus in the laboratory and in the subarctic Pacific Ocean. Limnol Oceanogr 32:178-188

Daly KL (1990) Overwintering development, growth, and feeding of larval Euphausia superba in the Antarctic marginal ice zone. Limnol Oceanogr 35:1564-1576

Dalpadado P (1993) Some observations on the feeding eco- 
logy of Norwegian Spring Spawning Herring Clupea harengus along the coast of Norway. ICES CM (1993)/L:47

Dawidowicz P, Loose CJ (1992) Metabolic costs during predator-induced diel vertical migration of Daphnia. Limnol Oceanogr 37:1589-1595

Drits AV, Pasternak AF (1993) Feeding of dominant species of the Antarctic herbivorous zooplankton. In: Voronina NM (ed) Pelagic ecosystems of the Southern Ocean. Nauka Press, Moscow, p 250-259

Drits AV, Semenova TN (1989) Trophic characteristics of major planktonic herbivores from the South Shetland Islands region during early spring. In: Ponomareva LA (ed) Complex investigations on the pelagic zone of the Southern Ocean. Shirshov Institute of Oceanology Publishers, Moscow, p 66-78

Evans RA, Hopkins CCE (1981) Distribution and standing stock of zooplankton sound-scattering layers along the North Norwegian coast in February-March, 1978. Sarsia $66: 147-160$

Falk-Petersen S, Hopkins CCE (1981) Zooplankton sound scattering layers in North Norwegian fjords: interactions between fish and krill shoals in a winter situation in Ullsfjorden and Øksfjorden. Kieler Meeresforsch Sonderh 5: 191-201

Frost BW, Bollens SM (1992) Variability of diel vertical migration in the marine planktonic copepod Pseudocalanus newmani in relation to its predators. Can J Fish Aquat Sci 49:1137-1141

Gibbons MJ (1993) Vertical migration and feeding of Euphausia lucens at two $72 \mathrm{~h}$ stations in the southern Benguela upwelling region. Mar Biol 116:257-268

Giske J, Aksnes DL, Baliño BM, Kaartvedt S, Lie U, Tryti Nordeide J, Salvanes AGV, Wakili SM, Aadnesen A (1990) Vertical distribution and trophic interactions of zooplankton and fish in Masfjorden, Norway. Sarsia 75:65-81

Greene CH, Stanton TK, Wiebe PH, McClatchie S (1991) Acoustic estimates of Antarctic krill. Nature 349:110

Greene $\mathrm{CH}$, Widder EA, Youngbluth MJ, Tamse A, Johnson GE (1992) The migration behavior, fine structure, and bioluminescent activity of krill sound-scattering layers. Limnol Oceanogr 37:650-658

Greenlaw CF (1979) Acoustical estimation of zooplankton populations. Limnol Oceanogr 24: 226-242

Hopkins CCE, Falk-Petersen S, Tande K, Eilertsen HC (1978) A preliminary study of zooplankton sound scattering layers in Balsfjorden: structure, energetics, and migrations. Sarsia 64:255-264

Johnsen GH, Jakobsen PJ (1987) The effect of food limitation on vertical migration in Daphnia longispina. Limnol Oceanogr 32:873-880

Kaartvedt S, Aksnes DL, Aadnesen A (1988) Winter distribution of macroplankton and micronekton in Masfjorden, Western Norway. Mar Ecol Prog Ser 45:45-55

Kaartvedt S, Svendsen H (1990) Advection of euphausiids in a Norwegian fjord system subject to altered freshwater input by hydro-electric power production. J Plankton Res $12: 1263-1277$

Kerfoot WC (1985) Adaptive value of vertical migration: comments on the predation hypothesis and some alternatives. In: Rankin MA (ed) Migration: mechanisms and adaptive significance. Contrib Mar Sci 27, University of Texas, Port Aransas, p 91-113

Kirkerud LA (1974) Konsentrasjonen av kopper, sink, bly og kadmium (delvis også jern) målt i zooplankton-arter fra Oslofjorden og Skagerrak. MSc thesis, University of Oslo

Lindem T, Al Houar D (1993) EP500 - A system for processing and presentation of echogram data produced by the Sim- rad EY500/EK500 echo sounders. ICES CM (1993)/B:25

Loose CJ, Dawidowicz P (1994) Trade-offs in diel vertical migration by zooplankton: the costs of predator avoidance Ecology 75:2255-2263

Mauchline J (1980) The biology of euphausids. Adv Mar Biol 18:373-623

Mauchline J, Fisher LR (1969) The biology of euphausids Adv Mar Biol 7:1-454

McClatchie S (1985) Feeding behavior in Meganyctiphanes norvegica (M.Sars) (Crustacea:Euphausiacea). J Exp Mar Biol Ecol 86:271-284

McCree KJ (1981) Photosynthetically active radiation. In: Lange OL, Nobel P, Osmond B, Ziegler $\mathrm{H}$ (eds) Physiological plant ecology, Vol 12A, Encyclopedia of plant physiology. Springer-Verlag, Berlin, p 41-55

Onsrud MSR (1997) Distribution and diel vertical migration of Meganyctiphanes norvegica in the inner Oslofjord: Possible impact by physics, food and predators. MSc thesis, University of Oslo

Pearcy WG, Hopkins CCE, Grønvik S, Evans RA (1979) Feeding habits of cod, capelin, and herring in Balsfjorden, northern Norway, July-August 1978: the importance of euphausiids. Sarsia 64:269-277

Perissinotto $R_{1}$ Pakhomov EA (1996) Gut evacuation rates and pigment destruction in the Antarctic krill Euphausia superba. Mar Biol 125:47-54

Pieper RE (1979) Euphausiid distribution and biomass determined acoustically at $102 \mathrm{kHz}$. Deep-Sea Res 26:687-702

Ringelberg $J$ (1995) Changes in light intensity and diel vertical migration: a comparison of marine and freshwater environments. J Mar Biol Assoc UK 75:15-25

Roe HSJ (1983) Vertical distributions of euphausiids and fish in relation to light intensity in the Northeastern Atlantic. Mar Biol 77:287-298

Rosland R, Giske J (1994) A dynamic optimization model of the diel vertical distribution of a pelagic planktivorous fish. Prog Oceanogr 34:1-43

Rudjakov JA (1970) The possible causes of diel vertical migration of planktonic animals. Mar Biol 6:98-105

Sameoto DD (1980) Relationships between stomach contents and vertical migration in Meganyctiphanes norvegica, Thysanoessa raschii and $T$. inermis (Crustacea Euphausiacea). J Plankton Res 2:129-143

Sameoto D. Chochrane NA, Herman AW (1985) Response of biological acoustic backscattering to ships' lights. Can J Fish Aquat Sci 42:1535-1543

Sameoto D, Chochrane NA, Herman AW (1993) Convergence of acoustic, optical and net-catch estimates of euphausiid abundance: use of artificial light to reduce net avoidance. Can J Fish Aquat Sci 50:334-346

Sameoto D. Neilson J, Waldron D (1994) Zooplankton prey selection by juvenile fish in Nova Scotian Shelf basins. J Plankton Res 16:1003-1019

Simard Y, Lacroix G, Legendre L (1986) Diel vertical migrations and nocturnal feeding of a dense coastal krill scattering layer (Thysanoessa raschi and Meganyctiphanes norvegica) in stratified surface waters. Mar Biol 91:93-105

Simard Y, Mackas DL (1989) Mesoscale aggregations of euphausiid sound scattering layers on the continental shelf of Vancouver Island. Can J Fish Aquat Sci 46:1238-1249

Strickland JDH, Parsons TR (1972) A practical handbook of sea water analysis. Bull Fish Res Bd Can 167:1-310

Stuart V, Pillar SC (1990) Diel grazing patterns of all ontogenetic stages of Euphausia lucens and in situ predation rates on copepods in the southern Benguela upwelling region. Mar Ecol Prog Ser 64:227-241

Tiselius P, Kuylenstierna M (1996) Growth and decline of a 
diatom spring bloom: phytoplankton species composition. formation of marine snow and the role of heterotrophic dinoflagellates. J Plankton Res 18(2):133-155

Torgersen T (1995) Akustiske studier av fisk og makroplankton over kontinentalsokkelen og det ostlige Norskehavet, mars 1992; fordeling, atferd og metodiske problemer. MSc thesis, University of Oslo

Vedal J (1997) Dyreplankton ved overflaten og i dypere vannlag. Dognlige variasjoner i vertikalfordeling og tilknytning tll potensiell naering. MSc thesis, University of Oslo

Wassmann P (1991) Dynamics of primary production and sedimentation in shallow fjords and polls of western Norway. Oceanogr Mar Biol Annu Rev 29:87-154

Editorial responsibility: Otto Kinne (Editor),

Oldendort/Luhe, Germany
Williams R, Fragopoulu N (1985) Vertical distribution and nocturnal migration of Nyctiphanes couchi (Crustacea: Euphausiacea) in relation to the summer thermocline in the Celtic Sea. Mar Biol 89:257-262

Williamson CE, Sanders RW, Moeller RE, Stutzman PL. (1996) Utilization of subsurface food resources for zooplankton reproduction: implications for diel vertical migration theory. Limnol Oceanogr 41:224-233

Wurtzbaugh WA, Neverman D (1988) Post-feeding thermotaxis and daily vertical migration in a larval fish. Nature 333:846-848

Zar JH (1996) Biostatistical analysis. Prentice Hall International, Englewood Cliffs, NJ

Submitted: October 20, 1997; Accepted: May 15, 1998 Proofs received from author(s): August 21, 1998 